\title{
Conservation management for forest fungi in Estonia: the case of polypores
}

\author{
Asko Lóhmus ${ }^{1}$, Eike Vunk ${ }^{2} \&$ Kadri Runnel ${ }^{1}$ \\ ${ }^{1}$ Institute of Ecology and Earth Sciences, University of Tartu, Vanemuise 46, 51014 Tartu \\ E-mail: asko.lohmus@ut.ee \\ ${ }^{2}$ Estonian Environmental Board, Narva mnt. 7a, 15172 Tallinn
}

Dedicated to Professor Erast Parmasto (1928-2012)

\begin{abstract}
Conservation management for fungi has lagged behind animal and plant conservation, and remains largely restricted to protecting known locations of few conspicuous threatened species. We used Estonian polypores as an example of how conservation options can be systematically screened, based on the Red List of threatened species and in co-operation with practitioners. For a total of 61 species, we identified a broad range of management options representing diverse approaches (site protection; prescriptions of land use; protection of individuals; special management; protection via umbrella species). The results demonstrated the merits of systematic and multi-disciplinary assessments for fungal conservation and setting related research priorities. Our assessment also supported a theoretical expectation that some ecosystem conservation strategies should be explicitly designed based on functionally important groups of fungi. The advancement of fungal conservation appears largely dependent on co-operation between mycologists, conservationists and managers.
\end{abstract}

Kokkuvóte: Eesti metsade seenestiku looduskaitsevôttted torikseente näitel

Seenestiku looduskaitseks kasutatav vốttestik on märksa halvemini välja arendatud kui loomade ja taimede puhul ning hôlmab peamiselt silmatorkavate ohustatud liikide leiukohtade kaitset. Töös kirjeldatakse Eesti torikseente näitel, kuidas sobivaid looduskaitsevôtteid saab süstemaatiliselt valida - lähtuvalt ohustatud liikide nimestikust ja koostöös looduskaitsepraktikutega. Kokku eristati 61 ohustatud torikseeneliigi kaitseks lai valik vôtteid, mis hôlmasid erinevaid võimalusi alade kaitseks, üldisi maakasutusjuhiseid, isendite kaitset, intensiivseid kaitsevôtteid ja kaitset teiste liikide (katusliikide) kaudu. Tulemused näitavad süstemaatilise ja multidistsiplinaarse analüüsi efektiivsust seente kaitse ja sellega seotud uuringute planeerimisel. Analüüs kinnitas ka teoreetilist, torikseente funktsionaalsest tähtsusest lähtuvat eeldust, et mõned ökosüsteemide kaitse vôttestikud tuleks kujundada just seente ökoloogiast lähtuvalt. Seenestiku looduskaitse peamine edenemistingimus paistab niisiis olevat koostöö mükoloogide, looduskaitseteadlaste ja -praktikute vahel.

Keywords: biodiversity, conservation planning, sustainable forest management, wood-inhabiting fungi, woodland key habitats

\section{INTRODUCTION}

In less than one's lifetime, conserving of fungal biodiversity has developed from a provocative idea to an acknowledged management objective. An eminent Estonian mycologist, Professor Erast Parmasto (1928-2012), played an important role in this process both nationally and internationally, and particularly regarding his favourite study group - polypore fungi. During his career, Parmasto shifted his focus from forest pathogens (Parmasto, 1956) to those species that are sensitive to loss of old-growth forests (Parmasto \& Parmasto, 1997; Parmasto, 2001). In parallel, he increasingly used his popularizing skills for advocating practical conservation, such as delimiting 'key biotopes' in forests based on fungal indicators, protecting crucial sites for some rare species and establishing the first reserves for full fungal assemblages (Parmasto, 2002, 2012). In the current paper, written to honour Prof. Parmasto's $90^{\text {th }}$ anniversary, we describe a new development derived from his work: polypores as a major test group for a systematic approach to practical fungal conservation in Estonia.

The fact that conservation management for fungi has lagged behind conservation of animals and plants was acknowledged already in the 1990s (Moore et al., 2001), but the progress from a descriptive phase of conservation problems has remained slow (e.g., Heilmann-Clausen et al., 2015; Halme et al., 2017). Even at the turn of the 21 st century, almost the only management 
tool identified was to protect some of the best natural habitats for threatened fungal species or - if that knowledge was unavailable - to hope that the sites protected for plant diversity also protect fungi (Courtecuisse, 2001). As conservation biologists and managers, we argue that such slow progress has been only partly due to incomplete knowledge on conservation needs for fungi or the lack of mycologists, which were seen as major problems at that time (Moore et al., 2001). In our opinion, at least of equal importance has been poor engagement of mycologists with the community of conservation managers, land-use planners, and environmental politicians and thinkers. By 'engagement' we mean active role of mycologists for developing conservation objectives, knowledge platforms and management prescriptions useful for managers.

In this paper, we outline conservation options for Estonian polypores, as mapped in a co-work between mycologists and conservationists and using the red list of threatened species as a basis. The key activity was matching ecological requirements of each threatened species with the existing legal and institutional framework, and explicitly listing critical gaps in this framework and in the knowledge base. It was the first such attempt for any taxon group in Estonia; therefore, polypores served as a test group for all biota, not only fungi. Moreover, given that most polypores inhabit woodlands and play important ecological roles as decayers and parts of food-webs in these ecosystems (Junninen \& Komonen, 2009; Stokland et al., 2012), several conservation options ultimately address much broader objectives of ecosystem management. Thus, a comprehensive approach to polypore conservation illustrates a bidirectional link between conservation planning for species through ecosystem management, and for ecosystem management through the requirements of selected species.

\section{MATERIALS AND METHODS}

\section{The species list}

Our basic premise was that conservation management should focus on threatened species. Therefore, we assessed management options for every species categorized as Critically Endangered (CR), Endangered (EN) and Vulnerable
(VU) on the 2017 national Red List (see below). We also assessed two of 20 species in the category Near Threatened (NT) because of their potential as widespread 'umbrella species' (see below) for threatened species. We did not assess Data Deficient (DD) species, but we acknowledge those taxa as a distinct conservation survey priority in addition to the knowledge gaps identified for threatened species (Fig. 1).

Polypores were defined as a morphological group of mostly wood inhabiting Basidiomycetes distinguished by their poroid hymenophore. In Estonia this group consists of 222 species (K. Runnel, in prep.). In 2017, we assessed the national extinction risk for each species in this group, using the international Red List framework of categories and criteria developed by IUCN (2012) and their specifications of use for fungi (Dahlberg \& Mueller, 2012). This was the first full assessment of polypores; only a small subset had been assessed previously ( 3 species in 1998 and 23 in 2008). Altogether, 59 species were considered threatened, i.e. they face either an extreme (CR), very high (EN) or high risk (VU) of extinction in the wild (Appendix 1).

\section{The procedure of mapping conservation options}

Each threatened species was assessed in a three-step procedure (Fig. 1), using the knowledge both on its biological characteristics (abundance, ecology, detectability in the field) and the land-use regulations and traditions in Estonia. The results were formatted as fact sheets that are open for both official and public use and were discussed at a special workshop with environmental managers. In the case of four species that have national action plans, fact sheets were not compiled but the options were still assessed (mostly as described in the action plans).

In the first step, we selected feasible options among the five broad conservation approaches as outlined in the official guidelines for species action planning in Estonia (Anonymous, 2011). Two approaches refer to protecting confirmed locations of species presence, either at the scale of the habitat patch (I, site protection) or fruit-bodies and their immediate substrate (III, individual protection). In critical cases, these may be accompanied by special management approach (IV) that included, for instance, artificial 
creation of substrates, inoculation or facilitation of individuals in situ or ex situ or their transport to avoid extirpation. Two remaining approaches address species habitat conservation indirectly, either by facilitating or protecting habitats through sectoral guidelines (e.g., general rules for forest management; II) or by protecting other similarly or more sensitive species (umbrella species; V; see Roberge \& Angelstam, 2004).

In the second step, we identified whether the broad approaches selected would require specific legal basis. Most importantly, a species must be legally protected to enable targeted site protection for that species in Estonia. According to the Nature Conservation Act, there are three protection categories in Estonia; their main difference is the minimum proportion of the known population required to be protected (Category 1: 100\%; Category 2: 50\%; Category 3: 10\%). Currently, there are five polypore species in Category 1 (one of these, Inonotopsis subiculosa, is considered Regionally Extinct) and four species in each of the Categories 2 and 3. Our assessment included a revision of that categorization. Also, the special management approach (IV) can only be implemented based on the species' national Action Plan, which is an official document approved by the Environmental Board in Estonia.

In the third step, we outlined specific conservation options and management guidelines under the broad conservation approach selected. There was no pre-determined list of the options, so that the final list was developed as a summary of species-level considerations. We also described the knowledge gaps that were encountered while outlining the options, notably on how well the main habitat of the species had been surveyed, and prioritized these depending on how much they appeared to hinder actual conservation management.

Original information about ecological requirements of the threatened polypore species and the relevant management needs mainly came

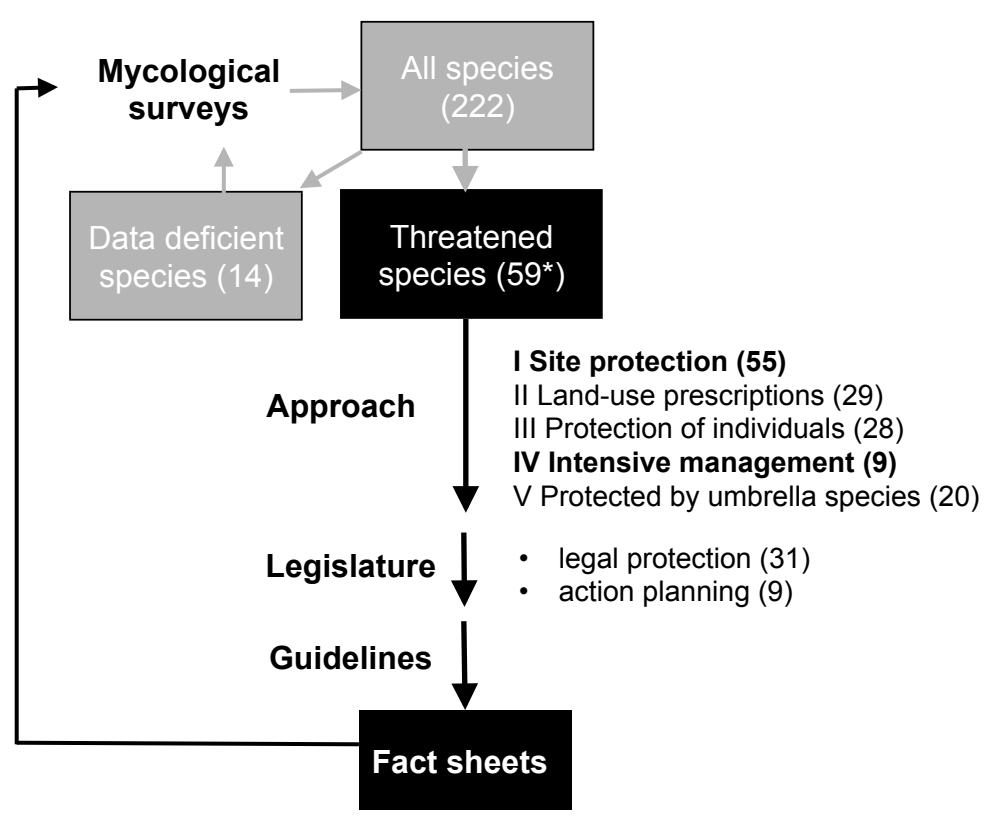

Fig. 1. Workflow of outlining conservation options for Estonian polypores (the number of species in parentheses; * two Near Threatened species were additionally assessed). For each threatened species, a three-step screening procedure was performed: (i) basic approaches were assigned and scrutinized in terms of (ii) legislature, and (iii) management guidelines, and survey priorities. The results were formatted as fact sheets. This procedure was preceded by red-listing. See text for further details. 
from two data sources. The first source were 174 systematic polypore surveys performed in 2-ha plots by the authors K.R and A.L over the past 12 years (Runnel et al., 2015; Runnel \& Lõhmus, 2017; and unpublished data). This sample represented the main forest types in Estonia and various stages of forest age and naturalness. Every plot had been surveyed for polypore fruit bodies using a fixed time $(4 \mathrm{~h})$ survey protocol, with the priority task to compile a species list. These surveys resulted in altogether ca. 20000 polypore records and also allowed to establish species absences. The second major source were the public databases Plutof and eElurikkus listing the species records in Estonia by (amateur) mycologists. These databases also include the historical information summarized by Parmasto (2004). Some additional data were found from national monitoring reports and results of fungal surveys in some reserves. We also considered the status and ecology in the neighboring countries, notably based on the recent polypore handbook for Finland (Niemelä, 2016), and the latest version of the Swedish Red List (ArtDatabanken, 2015).

\section{RESULTS}

In total, management options were mapped for all 59 nationally threatened polypores and, additionally, for two Near Threatened species (Royoporus badius and Skeletocutis stellae) (Appendix 1). For one of these 61 species, Ceriporia bresadolae, the current knowledge was too poor to allow distinguishing any management options. For three more species, the knowledge allowed delineating options that are preliminary at best - either due to unclear taxonomy (the information on Physisporinus vitreus and Polyporus tubaeformis involves cryptic taxa) or due to unknown ecology and distribution (Byssoporia terrestris).

We distinguished a total of 12 main management options (outlined below); and many additional species or ecosystem specific modifications. The most widely used approaches were related to site protection (three options; altogether relevant for 55 species) and land-use prescriptions (five options; 29 species) (Fig. 1). Considering the legal issues of site protection, we recommended a protection category for 31 species (14\% of all polypore species in Estonia): Category 1 - for 11 species (all red-listed as CR or VU); Category 2 for 11 species; Category 3 - for 9 species. Thus, strict legal protection appeared necessary in a minority of all cases where the site protection approach could be feasible.

\section{Site protection options}

\section{Woodland key-habitat assessment}

Description: after recording a threatened species, we recommend the formal key-habitat assessment procedure to assess broader values of the stand. In Estonia, the protection of key habitats is mandatory in FSC-certified forests, which include all state forests managed by the State Forest Management Centre (46\% of all forest land; Estonian Environmental Board, 2017). The advantages of this option are that it does not require legal protection of species and is applicable to a wide range of species (including poorly known or poorly detectable species).

Target: 32 species in a wide range of habitats, including traditionally managed woodlands (such as hazel groves for Antrodiella niemelaei) and disturbed forests (e.g., wildfire areas for Dichomitus squalens and Obba rivulosa). For two poorly known species (Polyporus tubaeformis, Postia ceriflua) it was the only suitable management option identified. Among the species listed, only Junghuhnia pseudozilingiana is officially a key-habitat indicator species in Estonia.

\section{Special site protection}

Description: the Minister of the Environment can protect, based on the Nature Conservation Act, known and officially registered localities of legally protected species as a 'species protection site'. In the case of Category 2 and Category 3 protected species, we recommend distinguishing priority sites based on multiple specimens found and the size of the habitat patch ( $>1 \mathrm{ha}$ ).

Target: 36 species in total, but a major tool probably for 20 protected species $(11$ species suggested for Category 1 and 9 species - for Category 2). The current usage is even less frequent because some target species are very rare and (almost) only found in already strictly protected reserves (e.g., Amylocystis lapponica, Antrodia mellita, Haploporus tuberculosus, Perenniporia tenuis, Pycnoporellus alboluteus); one species (Aurantiporus priscus) has not been found for $>30$ years. As of January 2018, only four special 
protected sites (total area $<2 \mathrm{ha}$ ) for two Category 1 fungal species (Grifola frondosa, Hapalopilus croceus) have been enforced in Estonia. However, retaining this option to protect new sites may be crucial for facilitating long-term recovery and connectivity of populations.

\section{Contributing to the forest reserve network on fertile soils}

Description: we assessed the potential value of a process initiated by the Minister of the Environment in 2017 - to strictly protect ca. 26,000 ha of meso-eutrophic and eutrophic forests. These site types have been long under intensive timber harvesting pressure and constitute the most important gap in the network of strictly protected forests in Estonia (Lõhmus et al., 2004). We found that, although the current habitat quality of the planned reserves is low due to their management history (e.g., Lõhmus \& Palo, 2017), they could act as crucial buffers against habitat loss in production forests (see also options 4-5) and specifications of the management regime based on fungi are thus well justified.

Target: important for 24 species, including 16 species with scattered and/or poorly known distributions, for which it is the most important site protection option due to large total area. Five spruce-dwelling polypores (Antrodia cretacea, A. piceata, Sarcospora polyspora, Skeletocutis odora, S. stellae) could serve as long-term indicators to measure the recovery of those newly protected forests.

\section{Land-use prescriptions}

4. Increasing pools of spruce coarse woody debris

Description: in unprotected areas potentially important for threatened species (e.g. around known localities), we recommend increasing spruce (Picea abies) coarse woody debris pool through specific forest management instructions. Such management should counteract the ongoing decline of old spruce stands in production forests caused by heavy demand by the forest industry and related lowering of the rotation age. In Estonia, such special management is most convenient in the restricted-management zones of reserves where management rules can include requirements for increased rotation age, and selective and more abundant preservation of dead wood of particular tree species.
Target: nine spruce-dwelling species, for which population facilitation is recommended because the protected local populations are generally very small. When combined with site-protection measures, this option could be crucial both for old-forest species (e.g., Antrodia piceata), disturbance-preferring species (e.g., Antrodia cretacea) and spruce-dwellers whose threat factors are poorly understood (e.g., Inonotus leporinus).

\section{Sustaining old aspen stands}

Description: improve silvicultural techniques for aspen (Populus tremula) management (e.g., Lõhmus, 2011). The management should counteract the predicted decline of old aspen area both in strict reserves (due to succession) and in production forests where the current rules allow harvesting most aspen stands at 30-40 years of age. The techniques could combine, for example, patch retention of aspens at clear-cutting and natural regeneration of the cutovers, or selective harvest techniques in aspen stands; these can - similarly to the option 4 above - most conveniently be applied in the restricted-management zones within reserves.

Target: high potential for six threatened species, including some (e.g., Antrodia leucaena, Aporpium macroporum) that are difficult to address otherwise due to their poor identificability.

6. Regulating the removal of dead-wood in specific places

Description: regulating dead wood removal is a management option for diverse situations, specifically when managing for predicted (future) occurrence of a species (e.g., based on ecology and distribution pattern). Such regulations apply, for example, to planned salvage logging of windthrows (inhabited by, e.g., Antrodia cretacea) or wildfire areas (Dichomitus squalens); removal of old dead trees (e.g., Perenniporia medulla-panis) or woody litter (Xanthoporia syringae) during the maintenance of parks or wooded meadows; and conifer stump crushing or harvesting in clear-cuts (Hapalopilus aurantiacus and $H$. ochraeolateritius). Two species may conflict with ecological restoration: Botryodontia millavensis in the case of removing old and/or dead junipers (Juniperus communis) when restoring open alvars, and Postia luteocaesia when clearing drained Scots pine (Pinus sylvestris) stands for mire restoration. 
Target: 12 species significantly affected (examples above).

7. Restricting timber harvesting in riverine deciduous forests

Description: we recommend a precautionary approach to timber harvesting in riverine deciduous stands that are situated in regions of frequent occurrence of threatened species. Whenever feasible, survey the sites before harvesting, and consider prolonged rotation age and retention of large patches that also contain dead wood.

Target: four threatened habitat specialists. Antrodia mellita and A. pulvinascens prefer large fallen aspens in riverine stands, including trees felled by beavers; Tyromyces fumidiceps and Physisporinus vitreus typically inhabit flooded forests.

\section{Improved live tree retention at final felling}

Description: our assessment focused on whether threatened species might benefit from improved practices compared with the current levels that already provide diverse habitats for woodinhabiting fungi (Runnel et al., 2013). We also separated the issue of patch retention of spruce and aspen in the restricted-management zones of reserves where it should be combined with other silvicultural prescriptions (options 4-5). Currently, the Forest Act prescribes $\geq 5 \mathrm{~m}^{3} \mathrm{ha}^{-1}$ of trees "for biodiversity" (live and dead trees not distinguished), and a field study has reported $15 \mathrm{~m}^{3} \mathrm{ha}^{-1}$ mean retention level of live trees $(6 \%$ of the growing stock; Rosenvald et al., 2008).

Target: Polyporus umbellatus and Sarcodontia spumea, which inhabit nemoral broadleaved trees - such as oak (Quercus robur) and elm (Ulmus glabra) - and have wooded grasslands as an alternative habitat. Because these tree species cannot reach overstories in even-aged production forests, we recommend to retain small tree groups comprising normal overstorey trees (of other species) and existing young nemoral broadleaves (see Lõhmus \& Runnel, 2014, for similar recommendation for lichens).

\section{Protection of individuals}

9. Fruit-body based approach to fungal protection

Description: protect the fruit body with the substrate that likely hosts (most of) the mycelium.
Target: although listed for 28 species, this option mostly serves as a preliminary and precautionary measure for avoiding harm to very rare species, and for enabling their spread by spores even if the surrounding habitat cannot or is not worth to be protected. In a few cases, it may be the crucial measure: for long-living species on old oaks (Hapalopilus croceus, Haploporus tuberculosus, Inocutis dryophila) or on other single old trees in semi-open habitats (Trametes gibbosa, T. suaveolens). In these cases, it is often useful to protect also adjacent, potentially suitable host trees that can be infected already or in perspective. Individual protection is important for Perenniporia tenuis - an extremely rare beautiful species potentially prone to collection; it was the single management option identified for Fibroporia vaillantii, which mostly inhabits moist rotten building timber with which it might be retained if acceptable to the owner.

\section{Special management}

\section{National action planning}

Description: Nature Conservation Act prescribes national action plans for every Category 1 protected species and in other cases where existing protection measures fail to ensure favourable conservation status. To avoid formality, we re-assessed the need for an action plan: as a prerequisite for enforcing special, often costly, management activities. Thus, we did not list action planning for five suggested Category 1 species, including one that has an existing plan (Grifola frondosa).

Target: 8 threatened species, three of which already have action plans (Amylocystis lapponica, Hapalopilus croceus and Haploporus tuberculosus).

\section{Active habitat/population management}

Description: the techniques relevant for woodinhabiting fungi include, for example, artificial creation of substrates, inoculation or facilitation of individuals in situ or ex situ or their transport to avoid extirpation (e.g., Abrego et al., 2016; Pasanen et al., 2018).

Target: for four species (Antrodia mellita, Haploporus tuberculosus, Inocutis dryophila, Pyconoporellus alboluteus) a need for active management is apparent even without explicit assessment in an action plan. 


\section{Umbrella species approach}

12. Management based on umbrella species and focal species

Description: manage for ecologically similar but better detectable species to facilitate target species indirectly - either by conserving its specific habitat (umbrella species; Roberge \& Angelstam, 2004) or by systematically addressing a range of threats (focal species; Lambeck, 1997). Polypore targets have not been previously assessed, but four non-threatened polypores have been suggested as focal species in a habitat modelling study (Runnel \& Lõhmus, 2017): the spruceinhabiting Fomitopsis rosea (red-listed as NT) and Pycnoporellus fulgens, aspen-inhabiting Oxyporus corticola and the pine pathogen Phellinus pini (all of Least Concern). Our analysis focused on poorly detectable (see Lõhmus, 2009), threatened habitat specialist species that shared the same habitat-related threats with well-known fungal or non-fungal species.

Target: 20 species. For eight threatened species, the umbrella approach was considered additional to special site protection (e.g., Antrodia piceata and Skeletocutis odora), while for most other species this option could best be combined with the key-habitat protection - another indirect measure. For one target species, Postia luteocaesia, an umbrella provided by the Capercaillie (Tetrao urogallus) conservation appeared as the main conservation option available. Other vertebrates distinguished as potential umbrella species included the Black Stork (Ciconia nigra) for Junghuhnia autumnale, and the Flying Squirrel (Pteromys volans) for Junghuhnia pseudozilingiana (which also serves as an umbrella species itself).

Besides $J$. pseudozilingiana, we identified four threatened polypores (Antrodia mellita, A. pulvinascens, Coltricia cinnamomea and Royoporus badius) that might be used as umbrella species for other threatened polypores. All these species inhabit deciduous wood or deciduous forests.

\section{DISCUSSION}

The most important lessons from our study are that (i) for practical fungal conservation many under-used options exist in addition to protecting well-known threatened species in their recorded locations; (ii) it requires systematic assessment to understand the relative importance of each option; and (iii) such systematic assessment is best accomplished in co-operation with practitioners and using multidisciplinary competence - to simultaneously address species, ecosystems, and social and economic context. Within such framework, we were, for example, able to provide explicit arguments for considerable enlarging of reserve network and for management regimes around strictly protected sites, and to outline both to mycologists and managers actions for the cases when threatened species are reported in the field. To balance fundamental criticism against the effectiveness of protecting key habitats (Rybicki \& Hanski, 2013), our analysis shows that this tool is potentially very useful from an administrative perspective; thus, there are good reasons to keep the system, but to increase the effective size and connectivity of key habitats. In contrast, while the value of retention trees for polypores has been highlighted in several studies both in Estonia and in neighbouring countries (Runnel et al., 2013; Suominen et al., 2015), our assessment indicates relatively little added value from further improvements for threatened species at the national scale. Instead, critical problems of clear-cutting are related to shortened rotations, which are most problematic in the case of aspen (see also Lõhmus, 2011). These points also reveal a dynamic perspective on fungal conservation - it can (and should) change along with the management decisions made for other purposes. To be able to adequately respond to such multi-level changes is the main reason why researcher-practitioner co-operation platforms are needed in the conservation in the long-term.

Importantly for researchers, their role in fungal conservation will increase, not decrease, with acknowledging conservation managers and policy makers as equal partners in discussions on fungal diversity. In fact, we see our explicit approach to conservation options as a broad set of testable research hypotheses - starting from applied questions of how fungal populations and assemblages respond to specific changes in their environment and, more widely, how they can survive in human-dominated ecosystems. Those responses, in turn, can lead to basic research questions on functioning of fungal populations (e.g., Molina et al., 2011). We highlight that such research is only starting to emerge world- 
wide. For example, Bernes et al. (2015) listed a total of 52 studies on various responses of non-lichenized fungi to conservation management in boreal and temperate forests. In Fennoscandia, pioneering assessments have been published on the effectiveness of key habitats (Junninen \& Kouki, 2006; Berglund \& Jonsson, 2008) and using umbrella species for conserving polypores (Hurme et al., 2008). However, only few of these studies actually address rare and threatened species, and many issues - such as the long-term effectiveness of large reserves, individual protection, and different legal protection mechanisms - remain poorly documented. For example, recent expansion of records in Estonia suggests that large reserves have enabled a recovery and, possibly, re-occupation of Estonia by some old-forest polypores that were either restricted to single locations in eastern Estonia (Amylocystis lapponica, Antrodiella citrinella) or not known in the $20^{\text {th }}$ century at all (Junghuhnia autumnale, Pycnoporellus alboluteus) (Parmasto, 2004).

Within an explicit conservation framework, additional possibilities are also created for ecologists and amateur mycologists who can participate in collecting critically important data on the distribution, trends and ecology of particular species or species groups. Some major gaps revealed by our assessment were: (i) extensive molecular identification of fresh material of particular taxa with unclear or revised taxonomy, e.g. the threatened Aurantiporus priscus, Physisporinus vitreus and Polyporus tubaeformis (see above) and several Data Deficient species (e.g., from genera Albatrellus, Ceriporia and Sidera); (ii) alternative methods for assessing the status of extremely poorly detectable, probably mycorrhizal threatened species (e.g., Anomoloma albolutescens, A. myceliosum, Byssoporia terrestris), e.g. molecular sampling of soil; (iii) studies of potentially threatened but insufficiently studied habitats, such as riverine forests, oak stands, and wooded grasslands with ancient trees, which may host key populations of threatened species; (iv) monitoring local populations of some extremely rare species, such as Amylocystis lapponica, Boletopsis leucomelaena, Hapalopilus croceus, Haploporus tuberculosus, Inocutis dryophilus, and Pycnoporellus alboluteus.

To summarize, we hope that our work shows a way to fungal conservation through systematic and multi-disciplinary assessments where both professional and amateur mycologists have a crucial role. The assessment also supported a theoretical expectation that certain ecosystem conservation techniques should be explicitly designed based on fungi. The advancement of fungal conservation will depend much on cooperation skills of mycologists, conservationists and managers.

\section{ACKNOWLEDGEMENTS}

We are grateful to Indrek Sell, Kristjan Ait, Toomas Hirse and Kaisa Junninen for constructive discussions on polypore management. Gregory Mueller, Piret Lõhmus and Liina Remm kindly commented on the first draft, and Anders Dahlberg provided a thorough review. Financial support was provided by the Estonian Centre of Environmental Investments (project 11061) and the Estonian Research Council (grant IUT 34-7).

\section{REFERENCES}

Abrego, N., Oivanen, P., Viner, I., Nordén, J., Penttilä, R., Dahlberg, A., Heilmann-Clausen, J., Somervuo, P., Ovaskainen, O. \& Schigel, D. 2016. Reintroduction of threatened fungal species via inoculation. Biological Conservation 203: 120-124. https://doi.org/10.1016/j.biocon.2016.09.014

Anonymous 2011. Juhendmaterjal liigi kaitse tegevuskava koostamiseks. MTÜ Põhjakonn. https:// www.keskkonnaamet.ee/sites/default/public/ Lisa3_Liigi_tegevuskavade_juhend_11102011_ fin 1.pdf (Accessed 4 January 2017)

ArtDatabanken, 2015. Rödlistade arter i Sverige 2015. ArtDatabanken SLU, Uppsala

Berglund, H. \& Jonsson, B.G. 2008. Assessing the extinction vulnerability of wood-inhabiting fungal species in fragmented northern Swedish boreal forests. Biological Conservation 141: 3029-3039. https://doi.org/10.1016/j.biocon.2008.09.007

Bernes, C., Jonsson, B.G., Junninen, K., Lõhmus, A., MacDonald, E., Müller, J. \& Sandström, J. 2015. What is the impact of active management on biodiversity in boreal and temperate forests set aside for conservation or restoration? A systematic map. Environmental Evidence 4: 25. https: / / doi. org/10.1186/s13750-015-0050-7

Cortecuisse, R. 2001. Current trends and perspectives for the global conservation of fungi. In: Moore, D. et al. (eds.) Fungal Conservation. Issues and Solutions: 7-18. Cambridge University Press, Cambridge. https://doi.org/10.1017/ CBO9780511565168.003

Estonian Environmental Board 2017. Yearbook Forest 2016. Tallinn. 
Halme, P., Holec, J. \& Heilmann-Clausen, J. 2017. The history and future of fungi as biodiversity surrogates in forests. Fungal Ecology 27: 193-201. https://doi.org/10.1016/j.funeco.2016.10.005

Heilmann-Clausen, J., Barron, E.S., Boddy, L., Dahlberg, A., Griffith, G.W., Nordén, J., Ovaskainen, O., Perini, C., Senn-Irlet, B. \& Halme, P. 2015. A fungal perspective on conservation biology. Conservation Biology 29: 61-68. https://doi. org/10.1111/cobi.12388

Hurme, E., Mönkkönen, M., Sippola, A.L., Ylinen, H. \& Pentinsaari, M. 2008. Role of the Siberian flying squirrel as an umbrella species for biodiversity in northern boreal forests. Ecological Indicators 8: 246-255. https://doi.org/10.1016/j. ecolind.2007.02.001

Junninen, K. \& Komonen, A. 2011. Conservation ecology of boreal polypores: a review. Biological Conservation 144: 11-20. https://doi.org/10.1016/j. biocon.2010.07.010

Junninen, K. \& Kouki, J. 2006. Are woodland key habitats in Finland hotspots for polypores (Basidiomycota)? Scandinavian Journal of Forest Research 21: 32-40. https://doi. org/10.1080/02827580500530009

Lambeck, R.J. 1997. Focal species: a multi-species umbrella for nature conservation. Conservation Biology 11: 849-856. https://doi.org/10.1046/ j.1523-1739.1997.96319.x

Lõhmus, A. 2009. Factors of species-specific detectability in conservation assessments of poorly studied taxa: the case of polypore fungi. Biological Conservation 142: 2792-2796. https://doi. org/10.1016/j.biocon.2009.05.022

Lõhmus, A. 2011. Aspen-inhabiting Aphyllophoroid fungi in a managed forest landscape in Estonia. Scandinavian Journal of Forest Research 26: 212-220. https://doi.org/10.1080/02827581.2 011.558850

Lõhmus, A., Palo, A. 2017. Võimalused salumetsade range kaitse vajakute täitmiseks Eestis. https:// www.envir.ee/sites / default / files / raport_salukaitsealad_vers2.pdf (Accessed 29 June 2018)

Lõhmus, A., Kohv, K., Palo, A. \& Viilma, K. 2004. Loss of old-growth, and the minimum need for strictly protected forests in Estonia. Ecological Bulletins 51: 401-411.

Lõhmus, A. \& Runnel, K. 2014. Ash dieback can rapidly eradicate isolated epiphyte populations in production forests: a case study. Biological Conservation 169: 185-188. https://doi. org/10.1016/j.biocon.2013.11.031

Molina, R., Horton, T.R., Trappe, J.M. \& Marcot, B.G. 2011. Addressing uncertainty: how to conserve and manage rare or little-known fungi. Fungal Ecology 4: 134-146. https://doi.org/10.1016/j. funeco.2010.06.003

Moore, D., Nauta, M.M., Evans, S.E. \& Rotheroe, M. 2001. Fungal conservation issues: recognising the problem, finding solutions. In: Moore, D. et al. (eds.) Fungal Conservation. Issues and Solutions: 1-6. Cambridge University Press, Cambridge. https:/ / doi.org/10.1017/CBO9780511565168.002 Niemelä, T. 2016. Suomen käävät. Norrlinia 31: 1-432. Parmasto, E. 1956. Tähtsamate Eesti NSV torikuliste määraja. Loodusuurijate Selts Eesti NSV Teaduste Akadeemia juures, Tartu.

Parmasto, E. \& Parmasto, I. 1997. Lignicolous Aphyllophorales of old and primeval forests in Estonia. 1. The forests of northern Central Estonia with a preliminary list of indicator species. Folia Cryptogamica Estonica 31: 38-45.

Parmasto, E. 2001. Fungi as indicators of primeval and old-growth forests deserving protection. In: Moore, D. et al. (eds.) Fungal Conservation. Issues and Solutions: 81-88. Cambridge University Press, Cambridge. https://doi.org/10.1017/ CBO9780511565168.006

Parmasto, E. 2002. Liiva-Putla männik Saaremaal on kui loodud seenekaitsealaks. Eesti Loodus 53 (7/8): 24-25.

Parmasto, E. 2004. Distribution Maps of Estonian Fungi. III. Pore Fungi. Institute of Zoology and Botany of the Estonian Agricultural University, Tartu.

Parmasto, E., 2012. Bibliography of biological (mainly mycological) publications by Erast Parmasto. Folia Cryptogamica Estonica 49: 1-18.

Pasanen, H., Junninen, K., Boberg, J., Tatsumi, S., Stenlid, J. \& Kouki, J., 2018. Life after tree death: Does restored dead wood host different fungal communities to natural woody substrates? Forest Ecology and Management 409: 863-871. https:/ / doi.org/10.1016/j.foreco.2017.12.021

Roberge, J.M. \& Angelstam, P. 2004. Usefulness of the umbrella species concept as a conservation tool. Conservation Biology 18: 76-85. https:/ / doi. org/10.1111/j.1523-1739.2004.00450.x

Rosenvald, R., Lõhmus, A. \& Kiviste, A. 2008. Preadaptation and spatial effects on retention-tree survival in cut areas in Estonia. Canadian Journal of Forest Research 38: 2616-2625. https://doi. org/10.1139/X08-093

Runnel, K., Rosenvald, R. \& Lõhmus, A. 2013. The dying legacy of green-tree retention: different habitat values for polypores and wood-inhabiting lichens. Biological Conservation 159: 187-196. https:// doi.org/10.1016/j.biocon.2012.11.029

Runnel, K. \& Lõhmus, A. 2017. Deadwood-rich managed forests provide insights into the oldforest association of polypores. Fungal Ecology 27: 155-167. https://doi.org/10.1016/j.funeco.2016.09.006

Rybicki, J. \& Hanski, I. 2013. Species-area relationships and extinctions caused by habitat loss and fragmentation. Ecology Letters 16: 27-38. https:/ / doi.org/10.1111/ele.12065

Stokland, J.N., Siitonen, J. \& Jonsson, B.G. 2012. Biodiversity in Dead Wood. Cambridge University Press, Cambridge. https://doi.org/10.1017/ CBO9781139025843 
Appendix 1. Threatened polypore species and the conservation options assessed as relevant for their management in Estonia

\begin{tabular}{|c|c|c|c|c|c|c|c|}
\hline \multirow[b]{2}{*}{ Species ${ }^{a}$} & \multicolumn{2}{|l|}{ Category } & \multicolumn{5}{|c|}{ Approach and options ${ }^{d}$} \\
\hline & Red-list ${ }^{\mathrm{b}}$ & Legal $^{c}$ & Site protection & Land use & Individuals $^{\mathrm{e}}$ & $\begin{array}{l}\text { Special } \\
\text { management }\end{array}$ & Umbrella \\
\hline Abortiporus biennis & $\mathrm{VU}^{*}$ & & 1 & & 9 & & \\
\hline Amylocystis lapponica & $\mathrm{CR}^{*}$ & 1 & 2 & 4 & 9 & 10 & \\
\hline Anomoloma albolutescens & $\mathrm{EN}^{*}$ & & 1,3 & & & & \\
\hline Anomoloma myceliosum & $\mathrm{VU}^{*}$ & & 1,3 & & & & \\
\hline Antrodia cretacea & EN & 2 & $1-3$ & 4,6 & 9 & & 12 \\
\hline Antrodia gossypium & $\mathrm{VU}^{*}$ & & 1 & & & & 12 \\
\hline Antrodia leucaena & $\mathrm{vU}$ & & 3 & 5 & & & \\
\hline Antrodia mellita & $\mathrm{EN}^{*}$ & 1 & 2 & 7 & 9 & 10,11 & \\
\hline Antrodia piceata & EN & 1 & 2,3 & 4 & & & 12 \\
\hline Antrodia pulvinascens & $\mathrm{VU}^{*}$ & 2 & 2,3 & 5,7 & & & \\
\hline Antrodiella niemelaei & $\mathrm{VU}^{*}$ & & 1,3 & 6 & & & \\
\hline Antrodiella parasitica & $\mathrm{EN}^{*}$ & & 1,3 & & & & 12 \\
\hline Aporpium macroporum & $\mathrm{vU}$ & & 1,3 & 5 & & & 12 \\
\hline Aurantiporus priscus & $\mathrm{CR}$ & 1 & 2 & 6 & 9 & & \\
\hline Boletopsis grisea & $\mathrm{VU}^{*}$ & 3 & 2 & & & & \\
\hline Boletopsis leucomelaena & $\mathrm{EN}$ & 1 & 2 & & & 10 & \\
\hline Botryodontia millavensis & $\mathrm{VU}^{*}$ & 3 & 2 & 6 & 9 & & \\
\hline Byssoporia terrestris & $\mathrm{VU}^{*}$ & & 3 & & & & \\
\hline Ceriporia bresadolae & $\mathrm{EN}^{*}$ & & & & & & \\
\hline Ceriporia tarda & $\mathrm{CR}^{*}$ & 2 & 1,2 & & 9 & & \\
\hline Ceriporiopsis jelicii & $\mathrm{EN}^{*}$ & & 1,3 & & 9 & & \\
\hline Coltricia cinnamomea & $\mathrm{VU}^{*}$ & 2 & 2,3 & & & & \\
\hline Dichomitus squalens & EN & 3 & 1,2 & 6 & & & \\
\hline Fibroporia vaillantii & $\mathrm{VU}^{*}$ & & & & 9 & & \\
\hline Grifola frondosa & $\mathrm{CR}^{*}$ & 1 & 2 & & 9 & & \\
\hline Hapalopilus aurantiacus & $\mathrm{EN}^{*}$ & 3 & 2 & 6 & 9 & & \\
\hline Hapalopilus croceus & $\mathrm{CR}^{*}$ & 1 & 2 & & 9 & 10 & \\
\hline Hapalopilus ochraceolateritius & $\mathrm{EN}^{*}$ & 3 & 2 & 6 & 9 & & \\
\hline Haploporus tuberculosus & $\mathrm{CR}^{*}$ & 1 & 2 & & 9 & 10,11 & \\
\hline Hyphodontia latitans & EN & & 1,3 & & & & 12 \\
\hline Inocutis dryophila & $\mathrm{CR}^{*}$ & 2 & 2 & & 9 & 10,11 & \\
\hline Inonotus leporinus & EN & 2 & $1-3$ & 4 & 9 & & \\
\hline Junghubnia autumnale & $\mathrm{VU}^{*}$ & & 1,3 & & 9 & & 12 \\
\hline Junghuhnia fimbriatella & EN & & 1,3 & 5,6 & & & 12 \\
\hline Junghuhnia pseudozilingiana & VU & 3 & 1,2 & 5 & & & 12 \\
\hline
\end{tabular}


Appendix 1. (continued)

\begin{tabular}{|c|c|c|c|c|c|c|c|}
\hline \multirow[b]{2}{*}{ Species $^{\mathrm{a}}$} & \multicolumn{2}{|l|}{ Category } & \multicolumn{5}{|c|}{ Approach and options ${ }^{d}$} \\
\hline & Red-list $^{\mathrm{b}}$ & Legal $^{c}$ & Site protection & Land use & Individuals $^{\mathrm{e}}$ & $\begin{array}{l}\text { Special } \\
\text { management }\end{array}$ & Umbrella \\
\hline Lindtneria trachyspora & $\mathrm{EN}^{*}$ & 2 & 2 & & & & 12 \\
\hline Obba rivulosa & $\mathrm{EN}^{*}$ & 2 & 1 & & & & 12 \\
\hline Oxyporus latemarginatus & $\mathrm{EN}^{*}$ & & 3 & 6 & 9 & & \\
\hline Oxyporus ravidus & $\mathrm{EN}^{*}$ & & 1,3 & & & & \\
\hline Perenniporia medulla-panis & $\mathrm{EN}^{*}$ & 1 & 1,2 & 6 & 9 & 10 & \\
\hline Perenniporia tenuis & CR & 1 & 2 & & 9 & & \\
\hline Physisporinus vitreus & $\mathrm{VU}^{*}$ & & 1 & 7 & & & \\
\hline Polyporus melanopus & $\mathrm{VU}^{*}$ & & 1,2 & & & & \\
\hline Polyporus tubaeformis & $\mathrm{VU}^{*}$ & & 1 & & & & \\
\hline Polyporus umbellatus & $\mathrm{EN}^{*}$ & & 1,2 & 8 & 9 & & \\
\hline Postia ceriflua & $\mathrm{EN}^{*}$ & & 1 & & & & \\
\hline Postia hibernica & $\mathrm{VU}^{*}$ & & 1 & & & & 12 \\
\hline Postia luteocaesia & $\mathrm{VU}^{*}$ & & & 6 & & & 12 \\
\hline Pycnoporellus alboluteus & $\mathrm{CR}^{*}$ & 1 & 2 & 4 & 9 & 10,11 & \\
\hline Royoporus badius & NT & & 3 & 5 & & & \\
\hline Sarcodontia spumea & $\mathrm{VU}^{*}$ & & 1 & 8 & 9 & & 12 \\
\hline Sarcoporia polyspora & $\mathrm{EN}^{*}$ & 2 & $1-3$ & 4 & & & 12 \\
\hline Sidera lenis & $\mathrm{VU}^{*}$ & & 1,2 & 4 & & & 12 \\
\hline Skeletocutis brevispora & $\mathrm{CR}$ & & 1,3 & & 9 & & 12 \\
\hline Skeletocutis ochroalba & $\mathrm{EN}^{*}$ & & 1,3 & & & & 12 \\
\hline Skeletocutis odora & $\mathrm{VU}$ & 2 & $1-3$ & 4 & 9 & & 12 \\
\hline Skeletocutis stellae & $\mathrm{NT}^{*}$ & 3 & $1-3$ & 4 & 9 & & 12 \\
\hline Trametes gibbosa & $\mathrm{VU}^{*}$ & & & & 9 & & \\
\hline Trametes suaveolens & $\mathrm{CR}$ & 2 & & & 9 & & \\
\hline Tyromyces fumidiceps & $\mathrm{EN}^{*}$ & 3 & & 7 & & & \\
\hline Xanthoporus syringae & VU & 3 & 2 & 6 & & & \\
\hline
\end{tabular}

${ }^{a}$ species marked in Bold were assessed as research priorities

b according to Red List assessment in 2017; * based solely on the small population size (D-criterion)

${ }^{\mathrm{c}}$ protection category suggested based on the current study

${ }^{d}$ the numbers refer to management options as outlined in the text: 1 -woodland key-habitat assessment; 2 special site protection; 3 - contributing to the forest reserve network on fertile soils; 4 - increasing pools of spruce coarse woody debris; 5 - sustaining old aspen stands; 6 - regulating the removal of dead-wood in specific places; 7 - restricting timber harvesting in riverine deciduous forests; 8 -improving live tree retention at final felling; 9 - fruit-body based approach to fungal protection; 10 - national action planning; 11 - active habitat/population management; 12 - management based on umbrella species and focal species.

${ }^{\mathrm{e}}$ here listed based on ecological relevance only; formally, the individuals of every species in protection categories 1 and 2 must be protected according to the Nature Conservation Act 
90 Folia Cryptog. Estonica 